\title{
Soil quality along the water course of selected distributory-4 of Shahapur branch canal of UKP command area
}

CHANDRAGOUDA GIRIGOUDAR, H. V. RUDRAMURTHY AND N. L. RAJESH

MEMBERS OF RESEARCH FORUM:

Corresponding author :

H. V. RUDRAMURTHY,

Department of Soil Science and Agricultural Chemistry, College of Agriculture (U.A.S.),

Bheemarayanagudi, YADAGIR (KARNATAKA) INDIA

Email: girigoudar1991@gmail.com

Co-authors :

CHANDRAGOUDA

GIRIGOUDAR AND N. L.

RAJESH, Department of Soil

Science and Agricultural Chemistry,

College of Agriculture, RAICHUR,

(KARNATAKA) INDIA
Received : 14.03.2017; Revised : 15.04.2017; Accepted : 27.04.2017

\section{Summary}

A survey work on quality of red soils along the water course of SBC carried out during 201415 which indicated that soil quality parameters such as WSA, MWHC AW, SEI, BD, total soil porosity, $\mathrm{pH}, \mathrm{SOC}, \mathrm{CEC}, \mathrm{MBC}$ and DHA were comparatively better in tail reach soils than in head and middle reach soils as the amount of water discharged at soils of later reaches was more than that of farmer reach and in general soil quality was not deteriorated as much as excepted as the land use was paddy the bellow ground portion of paddy crop is being incorporated into the soil year after the year added organic matter to the soil and in addition to this coarser soil texture did not encourage accumulation of salt in soils and thus, the significant correlation of soil quality parameter with both particle size classes and SOC was evident of it.

Key words : : Bulk density, Available water, Water stable aggregates, Soil erosion index, SOC, CEC, Microbial biomass carbon, Dehydrogenase activity

How to cite this article : Girigoudar, Chandragouda, Rudramurthy, H.V. and Rajesh, N.L. (2017). Soil quality along the water course of selected distributory-4 of Shahapur branch canal of UKP command area. Asian J. Soil Sci., 12 (1) : 71-79 : DOI : 10.15740/HAS/AJSS/12.1/71-79. 